\title{
Study on the Preparation of Silica Using Residues of Oil Shale
}

\section{Nie and T. Wang* \\ College of Construction Engineering, Jilin University, 6 Xi Min Zhu Street, Changchun 130 026, Jilin Province, P.R. China}

\begin{abstract}
$\|$ Abstract
Usage of oil shale produces abundant oil shale residue, which may not only directly cause serious pollution to the environment, but also result in a waste of resource. In this paper, acid leaching method and alkali soluble method were compared to obtain the optimum processing conditions for the preparation of white carbon black, which was determined as follows: the mass fraction of $\mathrm{NaOH}$ was $8 \%$, the alkali dissolving time was $5 \mathrm{~h}$, and the reaction temperature was $100{ }^{\circ} \mathrm{C}$. Then the performance characteristics of the obtained white carbon black were analysed by XRD, SEM and IR spectroscopy. The results showed that the product of silica has a particle size between $20-30 \mathrm{~nm}$ and a purity of $98.4 \%$. Preparation of the high quality white carbon black might be a good way to make sufficient and reasonable use of oil shale residues, which will bring many environmental and social benefits.
\end{abstract}

$\|$ Keywords

Residue of oil shale, silica, alkali dissolving, characterization

\section{Introduction}

With the increasing demands for energy and reduction of available petroleum resources, the long-term oil prices tend to increase. Oil shale has drawn much attention in recent years as an important alternative energy resource. However, the waste residue from each oil shale extraction method is fairly high. Even concerning the maximum oil content of oil shale (around $30 \%$ ), there will be $70 \%$ waste residue of the spent oil shale after retorting. ${ }^{1}$ The main components of oil shale waste are $\mathrm{SiO}_{2}, \mathrm{Al}_{2} \mathrm{O}_{3}, \mathrm{Fe}_{2} \mathrm{O}_{3}, \mathrm{MgO}, \mathrm{CaO}$ and $\mathrm{SO}_{3}$ etc. Besides, there are many kinds of trace elements, including poisonous and harmful elements. ${ }^{2}$ China and the United States have the largest oil shale ash heap in the world, but now there are only Estonia, Russia, Germany and another six countries utilizing the ash and slag. The analysis of the ash shows that it contains heavy metal elements and trace amounts of radioactive elements, which are very likely to cause pollution in water, soil and surrounding flora and fauna. How to effectively improve the comprehensive utilization of oil shale ash and increase the added value of oil shale resources is a technical problem to be solved.

White carbon black is a porous, white, amorphous substance with a large internal surface area, which has good resistance to acids, and is insoluble in water and acids (except for hydrofluoric acid). It is a kind of promising fine chemical widely used in rubbers, plastics, agrochemicals, paintings, medicines, and so on. ${ }^{4-6}$

Reports on the use of oil shale residue to make silica are prevalent in recent years. However, the experimental results turn out to be not good, and especially the low pu- rity of the product seriously affects its application performance. $^{7-9}$ Therefore, in order to improve the application performance of silica generated from oil shale residue, further improvement of the preparation method is necessary.

\section{Materials and methods}

\subsection{Oil shale samples}

The oil shale used in this study was obtained from the open pit mine located in Fu Shun (FS), China. It was received as hard, dark grey blocks with no particular smell. After burning, breaking, and lapping, the samples were prepared. The chemical composition of the oil shale residue was obtained by X-ray fluorescence spectrometer (Table 1 ), in which $\mathrm{SiO}_{2}$ accounted for more than $60 \%$ of the oil shale residue.

Table 1 - Chemical composition of the semicoke of oil shale analysed by XRF

Tablica 1 - Kemijski sastav polukoksa naftnog škriljevca analiziran XRF-om

\begin{tabular}{c|r}
\hline $\begin{array}{c}\text { Component } \\
\text { Sastojak }\end{array}$ & $w / \%$ \\
\hline $\mathrm{SiO}_{2}$ & 63.52 \\
$\mathrm{Al}_{2} \mathrm{O}_{3}$ & 26.21 \\
$\mathrm{Fe}_{2} \mathrm{O}_{3}$ & 3.13 \\
$\mathrm{TiO}_{2}$ & 0.78 \\
$\mathrm{CaO}$ & 4.31 \\
$\mathrm{MgO}$ & 0.22 \\
$\mathrm{~K}_{2} \mathrm{O}$ & 1.08 \\
$\mathrm{Na}_{2} \mathrm{O}$ & 0.76 \\
\hline
\end{tabular}




\subsection{Comparison of alkaline and acid methods}

\subsubsection{The preparation of silica by acid method}

In the acid dissociation method, metal oxides and $\mathrm{H}_{2} \mathrm{SO}_{4}$ reacted easily to produce soluble metal ions, so that $\mathrm{Al}_{2} \mathrm{O}_{3}$, $\mathrm{Fe}_{2} \mathrm{O}_{3}$ could be separated from $\mathrm{SiO}_{2}$ after filtration. In addition, $\mathrm{SiO}_{2}$ changed from crystal structure to amorphous structure and silica was obtained.

The reaction equations are:

$$
\begin{aligned}
& \mathrm{Al}_{2} \mathrm{O}_{3}+3 \mathrm{H}_{2} \mathrm{SO}_{4} \rightarrow \mathrm{Al}_{2}\left(\mathrm{SO}_{4}\right)_{3}+3 \mathrm{H}_{2} \mathrm{O} \\
& \mathrm{Fe}_{2} \mathrm{O}_{3}+3 \mathrm{H}_{2} \mathrm{SO}_{4} \rightarrow \mathrm{Fe}_{2}\left(\mathrm{SO}_{4}\right)_{3}+3 \mathrm{H}_{2} \mathrm{O}
\end{aligned}
$$

Sulfuric acid of a certain concentration was added into a round-bottom flask, preheated to $90{ }^{\circ} \mathrm{C}$ in a constant temperature water bath, with the quick addition of $10 \mathrm{~g}$ of the calcined oil shale residue and magnetically stirred..$^{10-16}$

In order to study the influence of the concentration of $\mathrm{H}_{2} \mathrm{SO}_{4}$ on the leaching rate of $\mathrm{SiO}_{2}$, adopted were four different concentrations of $\mathrm{H}_{2} \mathrm{SO}_{4}$ analysis. The outcomes of different concentrations of $\mathrm{H}_{2} \mathrm{SO}_{4}$ are shown in Table 2.

Table 2 - Leaching rates of $\mathrm{SiO}_{2}$ at different concentrations of $\mathrm{H}_{2} \mathrm{SO}_{4}$

Tablica 2 - Brzine izluživanja $\mathrm{SiO}_{2}$ pri različitim koncentracijama $\mathrm{H}_{2} \mathrm{SO}_{4}$

\begin{tabular}{c|c}
\hline$C\left(\mathrm{H}_{2} \mathrm{SO}_{4}\right) /$ mol l$^{-1}$ & $\begin{array}{c}\text { Leaching rate of } \mathrm{SiO}_{2} / \% \\
\text { Brzina izluživanja } \mathrm{SiO}_{2} / \%\end{array}$ \\
\hline 1.0 & 18.3 \\
5.0 & 28.5 \\
8.5 & 42.3 \\
10.0 & 44.2 \\
\hline
\end{tabular}

The results showed that the leaching rate of $\mathrm{SiO}_{2}$ increased along with the concentration of $\mathrm{H}_{2} \mathrm{SO}_{4}$. When the concentration of $\mathrm{H}_{2} \mathrm{SO}_{4}$ was low, not only was the leaching rate of silica low, but also the silica colour was not white, suggesting the quality of the product was low. When $1.0 \mathrm{ml} \mathrm{H}_{2} \mathrm{SO}_{4}$ was used, the colour of the obtained silica was earthy red, indicating $\mathrm{Fe}^{3+}$ existed in the white carbon black. The acid dissociation method can exclude $\mathrm{Fe}^{3+}$ from the oil shale, thus it can influence the quality of obtained silica effectively.

\subsubsection{Preparation of silica by alkaline method}

Alkali method mainly uses the reaction of oil shale ash, $\mathrm{SiO}_{2}, \mathrm{Al}_{2} \mathrm{O}_{3}$ and $\mathrm{NaOH}$ to generate water soluble $\mathrm{Na}_{2} \mathrm{SiO}_{3}$, and separate the $\mathrm{Na}_{2} \mathrm{SiO}_{3}$ from the other components of the oil shale ash by filtration. To carry out the reaction successfully, the solution $\mathrm{pH}$ has to be controlled in a certain range. The reaction equations are:

$$
\begin{aligned}
& \mathrm{SiO}_{2}+2 \mathrm{NaOH} \rightarrow \mathrm{Na}_{2} \mathrm{SiO}_{3}+\mathrm{H}_{2} \mathrm{O} \\
& \mathrm{Na}_{2} \mathrm{SiO}_{3}+2 \mathrm{HCl} \rightarrow \mathrm{H}_{2} \mathrm{SiO}_{3}+2 \mathrm{NaCl}
\end{aligned}
$$

In the reaction, $10 \mathrm{~g}$ oil shale ash, $30 \mathrm{ml}$ water, and $15 \mathrm{~g}$ $\mathrm{NaOH}$ was added into a $250 \mathrm{ml}$ three-neck flask, and heated at $95{ }^{\circ} \mathrm{C}$ in a water bath to react for about $2 \mathrm{~h}$. The $\mathrm{pH}$ was adjusted to $8-9$ to produce white floc, then filtered. The rest of the residue was the white carbon black. ${ }^{17-23}$

In order to study the influence of the concentration of $\mathrm{NaOH}$ on the leaching rate of $\mathrm{SiO}_{2}$, reactions were carried out in different concentrations of $\mathrm{NaOH}$, and the leaching rates of $\mathrm{SiO}_{2}$ are shown in Table 3.

Table 3 - Leaching rates of $\mathrm{SiO}_{2}$ at different concentrations of $\mathrm{NaOH}$

Tablica 3 - Brzine izluživanja $\mathrm{SiO}_{2}$ pri različitim koncentracijama $\mathrm{NaOH}$

\begin{tabular}{c|c}
\hline$C(\mathrm{NaOH}) / \mathrm{moll}^{-1}$ & $\begin{array}{c}\text { Leaching rate of } \mathrm{SiO}_{2} / \% \\
\text { Brzina izluživanja } \mathrm{SiO}_{2} / \%\end{array}$ \\
\hline 0.8 & 10.2 \\
1.8 & 35.4 \\
2.8 & 40.3 \\
3.8 & 52.8 \\
5.0 & 58.2 \\
\hline
\end{tabular}

Results showed that the alkali concentration had a significant effect on the leaching rate of $\mathrm{SiO}_{2}$ (Table 3). By comparing the results listed in Table 2 and Table 3, it can be seen that the prepared silica by alkaline method was much higher than that with the acid extraction method. The alkaline dissolution method is more suitable for the industrial production of silica, so this study adopted the alkali dissolving methods to analyse the influence factors of the silicon extraction rate.

\subsection{Influence factors of the alkali dissolving method}

\subsubsection{Influence of the dissociation temperature}

To investigate the influence of dissociation temperature on the leaching rate of $\mathrm{SiO}_{2}$, the reaction temperature was changed to perform the preparation. The results indicated that by increasing the reaction temperature, the extraction rate of $\mathrm{SiO}_{2}$ had also increased (Fig. 1), which might be attributed to the improved diffusion and chemical reaction rates at higher temperature.

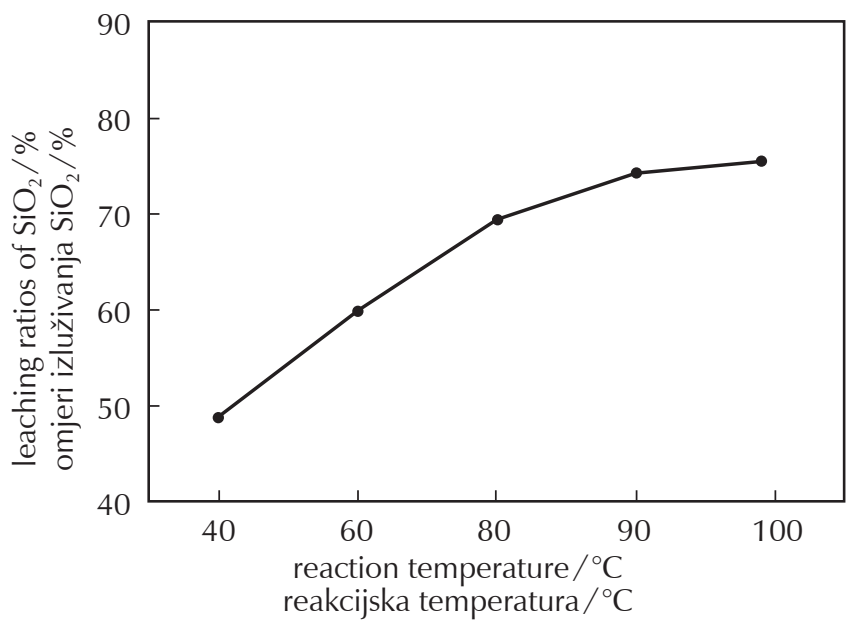

Fig. 1 - Influence of alkali solution temperature on the $\mathrm{SiO}_{2}$ extraction rate

Slika 1 - Utjecaj temperature lužnate otopine na brzinu ekstrakcije $\mathrm{SiO}_{2}$ 
The extraction rate of $\mathrm{SiO}_{2}$ increased rapidly with temperature up to $90{ }^{\circ} \mathrm{C}$, while it became stable in the range of 90-100 ${ }^{\circ} \mathrm{C}$. Considering the industrial steam heating, $100{ }^{\circ} \mathrm{C}$ might be the optimum extraction temperature.

\subsubsection{Influence of the dissociation time}

The effect of dissociation time was investigated at various times. As the reaction time proceeded, the extraction rate of $\mathrm{SiO}_{2}$ increased in the first $5 \mathrm{~h}$, after which it declined. A plausible explanation for this may be due to the separation of $\mathrm{Si}$ from the lattice, as the reaction lasted over $5 \mathrm{~h}$, and silicic acid precipitated on the remaining mineral surface, thus slowing down the reaction. Therefore, the appropriate dissociation time for the alkali might be $5 \mathrm{~h}$.

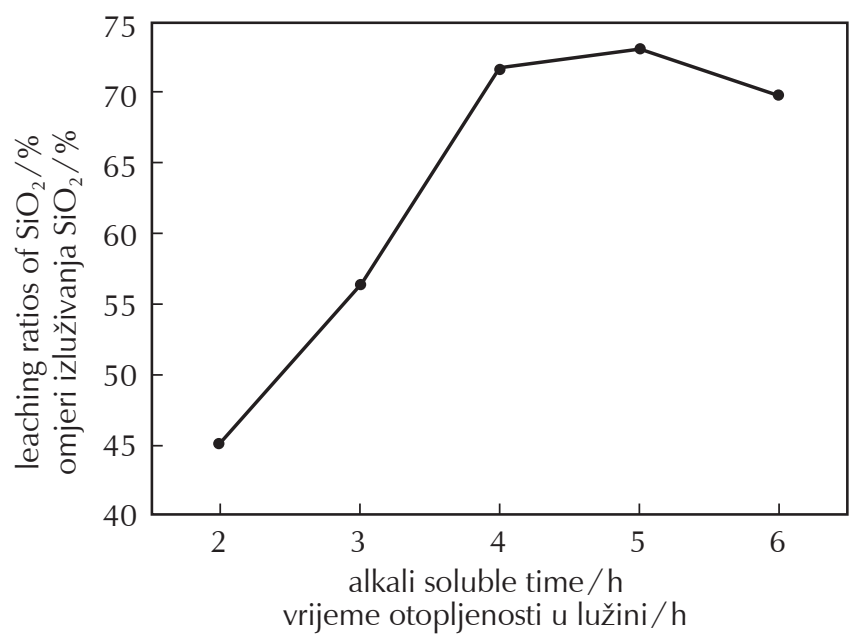

Fig. 2 - Influence of dissociation time on the $\mathrm{SiO}_{2}$ extraction rate Slika 2 - Utjecaj vremena disocijacije na brzinu ekstrakcije $\mathrm{SiO}_{2}$

\subsubsection{Determination of the amount of $\mathrm{NaOH}$}

The effect of the concentration of $\mathrm{NaOH}$ on the extraction rate was investigated.

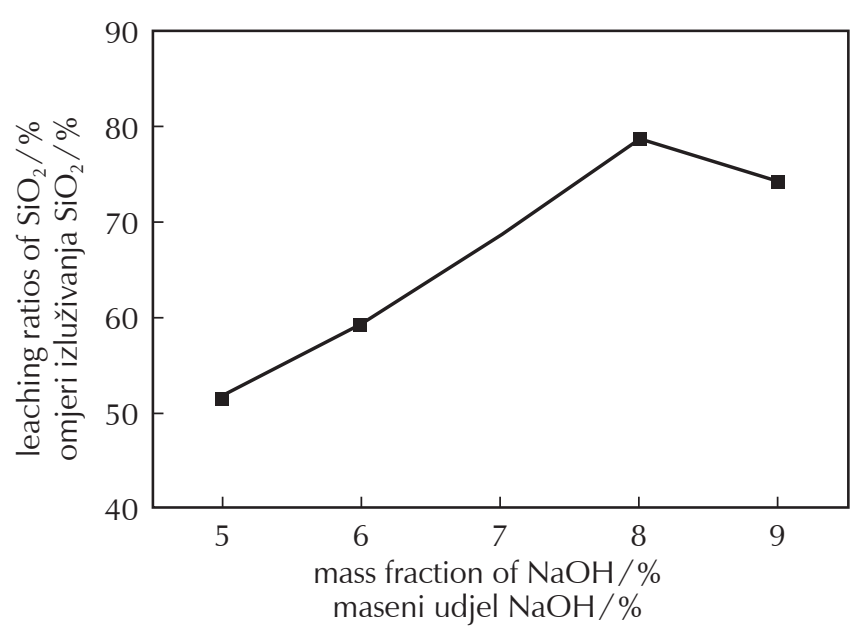

Fig. 3 - Effect of the mass fraction of $\mathrm{NaOH}$ on the $\mathrm{SiO}_{2}$ extraction rate

Slika 3 - Učinak masenog udjela $\mathrm{NaOH}$ na brzinu ekstrakcije $\mathrm{SiO}_{2}$
The results showed that the leaching rate increased as the mass fraction of $\mathrm{NaOH}$ increasing up to $8 \%$. When the mass fraction of $\mathrm{NaOH}$ was over $8 \%$, the extraction rate noticeably declined (Fig. 3). Extracting silica with sodium hydroxide is a solid-liquid multiphase chemical reaction, which may be controlled by diffusion or chemical reaction. In either case, the leaching rate is proportional to the concentration of sodium hydroxide. Because a portion of silica may be attached on the surface of the aluminum dross, the concentration of $\mathrm{NaOH}$ should be low; otherwise, the solution will exhibit high viscosity, resulting in difficulties in solid-liquid separation, and thus influencing the extraction rate.

\section{Results and discussion}

Silica as an important inorganic chemical raw material in industry that has many product indicators, including the contents of impurities, silicon dioxide, and so on. The performance characteristics of the obtained silica in this research was analysed by XRD spectrum, IR spectrum and SEM. ${ }^{24-25}$

\subsection{Purity analysis}

The purity of the product was analysed by X-ray fluorescence spectrometry, as shown in the following Table 4.

Table 4 - Composition of the silica obtained by the alkali dissolving method

Tablica 4 - Sastav silicijeva dioksida pripravljenog metodom otapanja lužinom

\begin{tabular}{c|c}
\hline $\begin{array}{c}\text { Component } \\
\text { Sastojak }\end{array}$ & $w / \%$ \\
\hline $\mathrm{SiO}_{2}$ & 98.4 \\
$\mathrm{Al}_{2} \mathrm{O}_{3}$ & 0.124 \\
$\mathrm{Fe}_{2} \mathrm{O}_{3}$ & 0.456 \\
$\mathrm{TiO}_{2}$ & 0.099 \\
$\mathrm{CaO}$ & 0.134 \\
$\mathrm{MgO}$ & 0.086 \\
$\mathrm{Cl}$ & 0.111 \\
$\mathrm{ZnO}$ & 0.014 \\
$\mathrm{SO}_{3}$ & 0.144 \\
$\mathrm{Na}_{2} \mathrm{O}$ & 0.428 \\
\hline
\end{tabular}

Results showed that there were very low amounts of impurities in the product.

\subsection{XRD analysis}

The crystal structure of the product recognition with XRD is shown in Fig. 4. 


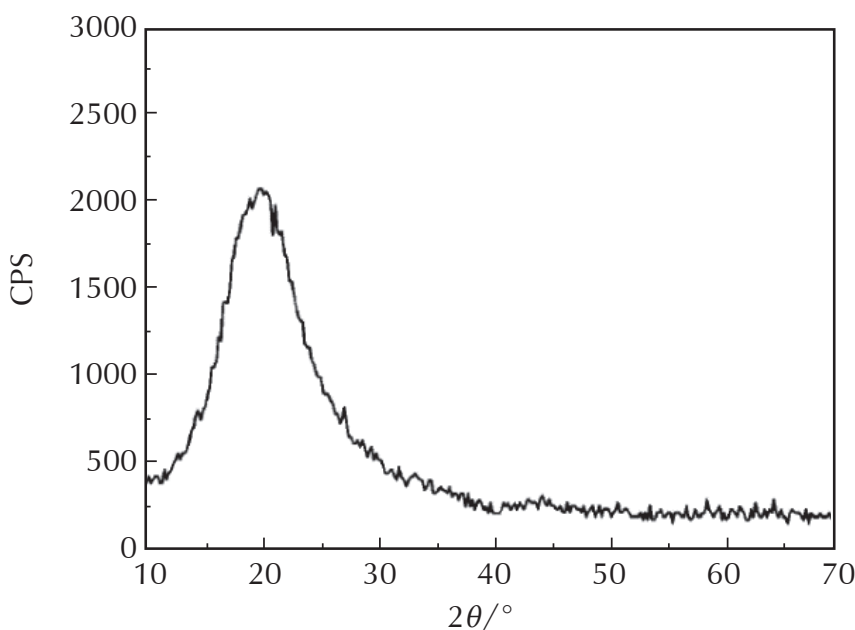

Fig. 4 - XRD spectrum of the silica product Slika 4 - XRD-spektar proizvoda silicijeva dioksida

The XRD spectrum of the $\mathrm{SiO}_{2}$ product did not show a sharp crystal diffraction peak, while only amorphous diffraction peaks appeared at $20-30^{\circ}$, indicating that the obtained products contained no other crystalline phases, and the product structure was amorphous.

\subsection{IR analysis}

In the infrared spectrum, the $1100 \mathrm{~cm}^{-1}$ and $466 \mathrm{~cm}^{-1}$ peaks represented the $\mathrm{Si}-\mathrm{O}-\mathrm{Si}$ bond of antisymetric stretching vibration, while the peak at $950 \mathrm{~cm}^{-1}$ represented the bending vibration. The $1640 \mathrm{~cm}^{-1}$ absorption peak indicated the bending vibration of surface water $\mathrm{H}-\mathrm{O}-\mathrm{H}$. The peak at $3400 \mathrm{~cm}^{-1}$ indicated the product internal structure of water (Fig. 5).

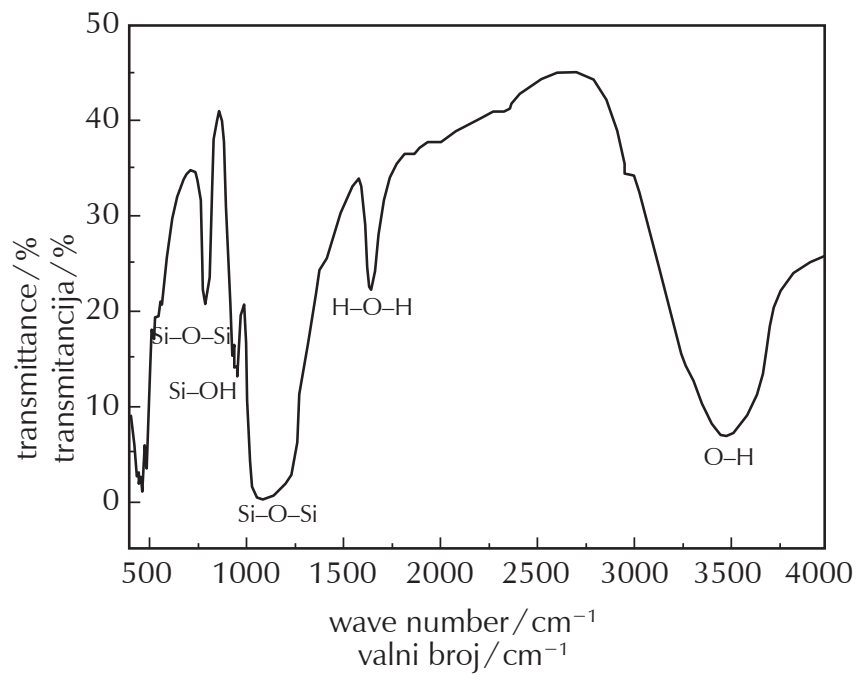

Fig. 5 - Infrared spectrum of the silica product

Slika 5 - Infracrveni spektar proizvoda silicijeva dioksida

\subsection{SEM analysis}

The results of the scanning electron microscope analysis of the product is shown in Fig. 6.

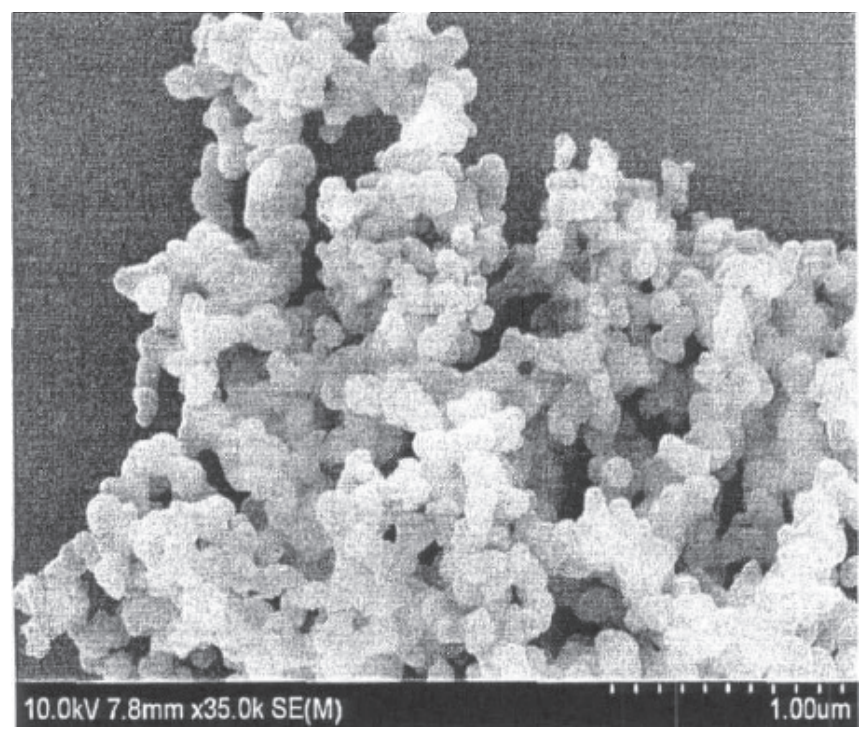

Fig. 6 -Scanning electron microscopy image of the silica product

Slika 6 - Slika proizvoda silicijeva dioksida snimljena skenirajućom elektronskom mikroskopijom

The SEM image showed that the product was in aggregation and the outline was not clear, which might be due to the internal temperature gradient of silica in the process of heating. Dehydration between the hydroxyl functional groups $(\mathrm{OH}-\mathrm{Si}-\mathrm{OH})$ caused the aggregation of the particles, whose size was between $20-30 \mathrm{~nm}$.

\section{Conclusions}

The alkali dissociation method is more suitable for the preparation of silica from oil shale residues than the acid dissociation method, because it results in a higher yield of $\mathrm{SiO}_{2}$.

The optimum conditions for the preparation of silica from FS oil shale residue are as follows: temperature $100^{\circ} \mathrm{C}$, mass fraction of $\mathrm{NaOH} 8 \%$, and alkali dissolving time $5 \mathrm{~h}$.

Through XRD, IR and SEM analysis, it was found that the produced silica had a purity of $98.4 \%$ and a particle size between $20-30 \mathrm{~nm}$, indicating the product is high-quality white carbon black. 


\section{List of symbols and abbreviations \\ Popis simbola i kratica}

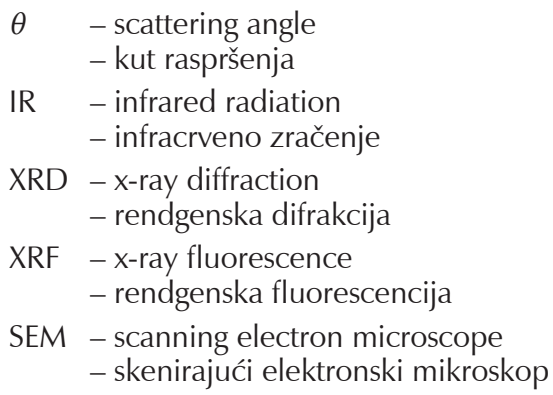

\section{References \\ Literatura}

1. H.-W. Jing, H.-Z. Liu, An experimental study on agricultural utilization of shale oil industrial soil waste, Nat. Sci. 37 (2001) 260-265.

2. A. Raukas, Oil shale industry and sustainability-governance through dialogue, Oil Shale. 22 (2005) 3-4.

3. Z.-J. Liu, R. Liu, Oil shale resource state and evaluating system, Earth Sci. Front. 12 (2005) 315-322.

4. J.-J. You, Y.-S. Qing, Comprehensive development and utilization of oil shale, Global J. Geol. Sci. 23 (2004) 261-265.

5. O. A. Ehinola, O. O. Sonibare, O. A. Akanbi, Economic evaluation, recovery techniques and environmental implications of the oil shale deposit in the Abakaliki anticliorium, Southeastern Nigeria, Oil Shale. 22 ( 2005) 5-9.

6. D.-H. Peng, J.-I.Qian, Oil shale activities in China, Oil Shale 8 (1991) 97-105.

7. Y.-H. Xue, T.-T. Guo, Z. Xue, Research on Preparation of White Carbon Black from Oil Shale Residue by Chemical Way, Multipurpose Util. Miner. Resour. 4 (2012) 40-42.

8. T. Kiipli, R. A. Batchelor, J. P. Bernal, C. Cowing, Seven sedimentary rock reference samples from Estonia, Oil Shale. 17 (2000) 215-223.

9. J.-G. Na, S.-H. Chung, K.-B. Lee, Effect of oil shale retorting temperature on shale oil yield and properties. Fuel. 95 (2012) 131-135, doi: http://dx.doi.org/10.1016/j. fuel.2011.11.029.

10. S.-H. Deng, Z.-J. Wang, Q. Gu, F.-Y. Meng, J.-F. Li, H.-Y. Wang, Extracting hydrocarbons from Huadian oil shale by sub-critical water, Fuel Process. Technol. 92 (2011) 1062-1067, doi: http://dx.doi.org/10.1016/j.fuproc.2011.01.001.

11. The national standard of the People's Republic of China, GB/T 13377; 2010 [Chinese].
12. The national standard of the People's Republic of China (Standard for soil test method) GB/T 50123; 1999 [Chinese].

13. X.-M. Jiang, X.-X. Han, Z.-G. Cui. Progress and recent utilization trends in combustion of Chinese oil shale, Prog Energy Combust Sci. 33 (2007) 552-579, doi: http://dx.doi. org/10.1016/j.pecs.2006.06.002.

14. M. V. Kök, Effect of clay on crude oil combustion by thermal analysis techniques. J. Therm. Anal. Calorim. 84 (2006) 361366, doi: http://dx.doi.org/10.1007/s10973-005-7153-2.

15. W. Henderson, G. Eglinton, P. Simmonds, J. E. Loveloc, Thermal alteration as a contributory process to the genesis of petroleum, Nature. 219 (1968) 1012-1016, doi: http://dx.doi. org/10.1038/2191012a0.

16. B. E. Scheetz, White Vibrational spectra of the alkaline earth double carbonates. Am. Mineral 62 (1977) 36-50.

17. K. Grice, S. Schouten, P. Blokker, S. Derenne, C. Largeau, A. Nissenbaum, Structural and isotopic analysis of kerogens in sediments rich in using thermal, X-ray and IR techniques, Fuel 84 (2005) 707-715, doi: http://dx.doi.org/10.1016/j. fuel.2004.11.013.

18. X.-Y. Qu, L. Liu, R. Ma, D.-Q. Hu, X. Chen, Y.-M. Wang, Experiment on debris-arkosic sandstone reformation by $\mathrm{CO}_{2}$ fluid, J. Jilin Univ. 38 (2008) 959-964.

19. G. R. L. Chalmers, D. K. Ross, R. M. Bustin, Geological controls on matrix permeability of Devonian Gas Shales in the Horn River and Liard basins, Northeaster British Columbia, Canada. Int. J. Coal. Geol. 103 (2012) 120-131, doi: http:// dx.doi.org/10.1016/j.coal.2012.05.006.

20. M. F. Martins, S. Salvador, J. F. Thovert, G. Debenest, Co-current combustion of oil shale-Part 1: Characterization of the solid and gaseous products, Fuel 89 (2010) 144 -151, doi: http://dx.doi.org/10.1016/j.fuel.2009.06.036.

21. O. Gavrilova, R. Vilu, L. Vallner, A life cycle environmental impact assessment of oil shale produced and consumed in Estonia, Resour. Conserv. Recy. 55 (2010) 232-245, doi: http://dx.doi.org/10.1016/j.resconrec.2010.09.013.

22. X.-M. Jiang, X.-X. Han, Z.-G. Cui, Progress and recent utilization trends in combustion of Chinese oil shale, Prog. Energy Combust. Sci. 33 (2007) 552-579, doi: http://dx.doi. org/10.1016/j.pecs.2006.06.002.

23. M. J. Adams, F. Awaja, S. Bhargava, S. Grocott, M. Romeo, Prediction of oil yield from oil shale minerals using diffuse reflectance infrared Fourier transform spectroscopy, Fuel. 84 (2005) 1986-1991, doi: http://dx.doi.org/10.1016/j. fuel.2005.04.011.

24. L.-H. Liu, Y. Suto, G. Bignall, N. Yamasaki, T. Hashida, $\mathrm{CO}_{2}$ injection to granite and sandstone in experimental rock/hot water systems, Energy Convers. Manage. 44 (2003) 1399-1410, doi: http://dx.doi.org/10.1016/S0196-8904(02)00160-7.

25. B. Liang, B. Lan, J.-G. Wang, Tri-axial compression test study on mechanical characteristics of oil shale under the water, J. Shandong Univ. 41 (2011) 82-85. 


\title{
SAŽETAK
}

\section{Studija o pripravi silicijeva dioksida uporabom ostataka iz naftnih škriljevaca}

\author{
Lei Nie i Tong Wang *
}

Uporabom naftnih (uljnih) škriljevaca nastaje obilje ostataka naftnog škriljevca, koji ne samo da mogu izravno uzrokovati ozbiljno onečišćenje okoliša, već i dovesti do gubitka resursa. U ovom radu provedena je usporedba metode izluživanja kiselinom i metode otapanja lužinom kako bi se dobili optimalni uvjeti za obradu i dobivanje bijele čađe, koji su određeni na sljedeći način: maseni udjel $\mathrm{NaOH}$ je $8 \%$, vrijeme otapanja u lužini je $5 \mathrm{~h}$ i temperatura reakcije $100{ }^{\circ} \mathrm{C}$. Potom su analizirane karakteristike dobivene bijele čađe pomoću XRD-a, SEM-a i IR spektroskopije. Rezultati su pokazali da proizveden silicijev dioksid ima veličinu čestica 20 - 30 nm i čistoću od 98,4 \% Priprava visokokvalitetne bijele čađe dobar je način za postizanje dovoljnog i razumnog korištenja ostataka naftnog škriljevca, koje može imati brojne ekološke i društvene koristi.

\section{Ključne riječi}

Ostatci naftnog škriljevca, silicijev dioksid, otapanje lužinom, karakterizacija

College of Construction Engineering Jilin University, 6 Xi Min Zhu Street Changchun 130026

Jilin Province

Kina
Izvorni znanstveni rad Prispjelo 5. veljače 2015. Prihvaćeno 19. svibnja 2015. 